\title{
Collaborative Learning: Design and Reflections in a Web Programming Course
}

\author{
Umadevi $\mathbf{V}^{1}$ \\ ${ }^{1}$ Department of Computer Science and Engineering, \\ BMS College of Engineering, Bangalore \\ ${ }^{1}$ umadevi.cse@bmsce.ac.in
}

\begin{abstract}
Collaborative learning enhances learning achievement and encourages student's responsibility of learning. Student Team Achievement Divisions (STAD) activity is a Collaborative learning in which small groups of students with different learning abilities work together to achieve common learning goal. In this work, design and reflections of STAD activity carried out for teaching a Web Programming course will be discussed. Relevantly, the quantitative and qualitative analysis results obtained by carrying out STAD activity demonstrates the positive impact of this methodology suitable for teaching a Web Programming course.
\end{abstract}

Keywords: Collaborative Learning, STAD, Web Programming Course

\section{Introduction}

Group of people learning something together is referred as "Collaborative Learning [1]." Two most important benefits of using Collaborative Learning is a. To enhance learning achievements and increasing social skills and $b$. To encourage student responsibility for learning [2]. Student Teams Achievement Division (STAD) is a type of Collaborative learning developed by Slavin and his colleagues [3]. In STAD, students work in four member heterogeneous teams to help each other master academic content. STAD is most appropriate for teaching well defined objectives, such as mathematical computations and applications, language usage and mechanics, geography and map skills, and science facts and concepts. In doing so, following steps were administrated in STAD [3][4].

Steps 1 Class Presentation - Content and teaching materials is introduced to students by instructor.

Step 2 Team Study - Group activity is carried out by which students are assigned to read the material. Team members consult each other to tackle the problems and correct the mistakes committed by team members. To achieve this, the cooperation of all team members is quite needed.

Step 3 Test - All individual learners themselves take the exam with no peer assistance intervention. They all are expected to do it best.

Step 4 Individual Improvement/Progress - is reported and determined on the basis of the calculation of the individual member's scores. Basically, the individuals are different in scores on basic knowledge.

Step 5 Team Recognition

Web Programming is an essential course in Bachelor of Engineering for Computer Science Stream of students. The main objective of the course for the students is to learn the concepts required in designing websites. The design of websites require a team of members working together for its completion. So during teaching this course by using only black board and monotone teaching will not make students to learn the concepts of Web Programming. In this work an attempt has been made to use STAD activity to teach the concepts of Web Programming. The quantitative and qualitative results of this activity demonstrated the positive use of this methodology in teaching this course. In the rest of the paper the design and reflections of STAD activity for this course will be discussed in detail. This paper is structured as follows. In Section 2, the Methodology adopted for STAD activity will be presented 
in detail. Results obtained by carrying out this activity will be discussed in Section 4. Finally, Section 5 includes some Conclusions and Recommendations for future work..

\section{Methodology}

STAD activity was carried out for 6th Semester students of Bachelor of Engineering for Computer Science Stream. The glimpse of the activity carried out is shown in Table I. Intervention in the experimental group was taken up two months after the beginning of the semester. The classes consisted of four face-to-face hours per week and 4 hours of laboratory classes distributed in 2 hours per week addressing different topics simultaneously.

Table I: Details of Collaborative Learning activity conducted

\begin{tabular}{|l|l|}
\hline \multicolumn{1}{|c|}{ Activity: } & \multicolumn{1}{c|}{$\begin{array}{c}\text { Student-Team-Achievement- } \\
\text { Divisions (STAD) }\end{array}$} \\
\hline Subject Name: & $\begin{array}{l}\text { "Web Programming" for 6th Sem, } \\
\text { B.E (CSE) }\end{array}$ \\
\hline $\begin{array}{l}\text { Topic of the Subject } \\
\text { for the Activity: }\end{array}$ & "DOM 2 Event Processing" \\
\hline $\begin{array}{l}\text { Number of Class } \\
\text { Sessions: }\end{array}$ & $\begin{array}{l}\text { Three } \\
\text { Class 1: Presentation of Lesson and } \\
\text { Team Formation } \\
\text { Class 2: Team discussion and Test } \\
\text { Class 3: Discussion of test answers } \\
\text { and Results }\end{array}$ \\
\hline Class Strength: & 44 \\
\hline Number of Groups: & $\begin{array}{l}11, \text { each group consisted of four } \\
\text { students }\end{array}$ \\
\hline
\end{tabular}

\section{A. Participants}

The total number of students in the class were 44 among which 15 were female and 29 were male students. For carrying out STAD the participants were divided into eleven heterogeneous groups. Each group had four students.

\section{B. Strategy}

Groups consisting of four students each were formed based on the class strength which was fourty four and eleven groups were created in total. It was into 8th week of teaching a subject "Web Programming" to the class. Until this point of time students had completed with their first internals and they had also completed a practical assignment work. Hence the performance (i.e. marks scored in the first internals and work carried out in practical assignment) of each student in the class was known.

Procedure that was followed to create heterogeneous groups is shown in Table II. First, to each group one student who was a Good Performer was allotted (i.e. a student who had scored greater than $85 \%$ in first internals and have submitted and completed their practical assignments in time). Second, to each group two Average Performers were allotted (i.e. a student whose marks in first internals was in the range of $60 \%$ to $85 \%$ and have submitted and completed their practical assignments in time). Third, to each group Low Performers were allotted (i.e. a student whose marks in first internals was less than
$60 \%$ and had not submitted their practical assignments in time).

Table II: Heterogeneous Team Formation Strategy

\begin{tabular}{|c|c|c|c|}
\hline $\begin{array}{c}\text { Group } \\
\text { Member 1 }\end{array}$ & $\begin{array}{c}\text { Group } \\
\text { Member } \\
\mathbf{2}\end{array}$ & $\begin{array}{c}\text { Group } \\
\text { Member 3 }\end{array}$ & $\begin{array}{c}\text { Group } \\
\text { Member 4 }\end{array}$ \\
\hline $\begin{array}{c}\text { Good } \\
\text { Performer }\end{array}$ & $\begin{array}{c}\text { Average } \\
\text { Performer }\end{array}$ & $\begin{array}{c}\text { Average } \\
\text { Performer }\end{array}$ & Low Performer \\
\hline $\begin{array}{c}\text { First Internals } \\
\text { marks }>85 \% ; \\
\text { Submitted \& } \\
\text { completed } \\
\text { practical } \\
\text { assignments in } \\
\text { time. }\end{array}$ & $\begin{array}{c}\text { First Internals marks was } \\
\text { in the range of 60 to 85\%; } \\
\text { Submitted \& completed } \\
\text { practical assignments in } \\
\text { time. }\end{array}$ & $\begin{array}{c}\text { First internals } \\
\text { marks }<60 \% ; \\
\text { not submitted } \\
\text { practical } \\
\text { assignments in } \\
\text { time }\end{array}$ \\
\hline \multicolumn{2}{|c}{} & \multicolumn{2}{|c}{} \\
\hline
\end{tabular}

The reason for following this strategy was that each group should have mixed performance students so that the Low performing student will ask and learn from Good and Average performing student or vice-versa.

C. Procedure

Before starting the STAD activity in the class, the description of the STAD activity was given, in which it was told them what they are supposed to do and discussed how it will be evaluated. Before the start of the activity, a presentation slide was displayed in the class which showed the team members name. For each team, a team leader was chosen i.e. Good performing student. To start the discussion, informed students to sit along with their respective team members.

D. Specific steps taken during STAD activity

Step 1: To Keep the discussion going amongst the team members

A reading material was supplied to each student for discussion and described the objective of the task. Informed students to read through the material, and call the instructor if they are not able to follow some of the text given. Instructor was moving around the class when discussion was going on so that the students are engaged in reading the material and discussing with the peers.

Step 2: To Motivate non-participating members

During discussion period, in some teams instructor observed and identified non-participating student by asking them some questions. For these students, instructor reminded them that each team members score will be summed up to find the total score of the team. Also for nonparticipating students, instructor explained the objective of studying the reading material topic given to them and explained them few things. After this it was observed that some non-participating students were getting involved into the activity.

\section{Step 3: To Open a deadlock}

For the discussion, instructor had supplied to the students a hardcopy of the study material, which was a 'Program' and 'DOM 2 Event Processing'. They were asked to read and discuss among the group members. After a few minutes of their discussion, it was observed that a few groups were 
finding it difficult or were not able to proceed or sitting with no progress. So instructor intervened and provided a lead by explaining them the topic by drawing a sample figure of program processing on their worksheets which helped them to catch up with the topic. After this the team was able to proceed.

Step 4: To keep the collaboration from wandering from objectives

When discussion was going on, instructor went around the teams and asked them few simple questions related to the topic. This was carried out to find out whether they are discussing towards the objective set for the task. Objective for the class collaborative activity set was that they should be focusing on going through the program given to them and correlate with DOM 2 Event processing topic to learn the concept of different phases of event registration. For a few teams, instructor asked the team leader to update on their progress.

Table III: Team-wise score of STAD activity

\begin{tabular}{|l|c|c|c|c|}
\hline Teams & $\begin{array}{c}\text { No. of } \\
\text { Students } \\
\text { Participat } \\
\text { ed* }\end{array}$ & $\begin{array}{c}\text { Maxi } \\
\text { mum } \\
\text { Mark } \\
\text { s }\end{array}$ & $\begin{array}{c}\text { Marks } \\
\text { Scored }\end{array}$ & $\begin{array}{c}\text { Total } \\
\text { \% }\end{array}$ \\
\hline Team 1 & 3 & 15 & 9 & 60 \\
\hline Team 2 & 2 & 10 & 1 & 10 \\
\hline Team 3 & 2 & 10 & 3 & 30 \\
\hline Team 4 & 3 & 15 & 11 & 73 \\
\hline Team 5 & 3 & 15 & 4 & 27 \\
\hline Team 6 & 2 & 10 & 9 & 90 \\
\hline Team 7 & 3 & 15 & 10 & 67 \\
\hline Team 8 & 4 & 20 & 10 & 50 \\
\hline Team 9 & 4 & 20 & 15 & 75 \\
\hline Team10 & 3 & 15 & 8 & 53 \\
\hline Team11 & 3 & 15 & 9 & 60 \\
\hline
\end{tabular}

\section{Results obtained and Discussion}

On the First day of collaborative activity, lesson was presented to the students and formed the heterogeneous teams as discussed in the previous section. But for the second day of the class *few team members were absent for the class, hence the number of students participated in each group varied. So the final score calculated was the percentage depending on the maximum score for that respective group. Team-wise score is shown in Table III.

Median Score of all the teams was 60 . Since the teams were heterogeneous, ideally all the teams should have secured a score equal to the median score. But this does not happen however. One of the most important reason for each team scoring less than the median score of the class and one most important reason why some teams outperformed is given in Table IV.

Table IV: Reasons for some teams scoring greater than and less than the Median score

\begin{tabular}{|c|l|}
\hline $\begin{array}{c}\text { Team } \\
\text { No. }\end{array}$ & Reason for scoring less than the median score \\
\hline 2 & $\begin{array}{l}\text { This team score was } 10 \% . \\
\text { This team had only two students, among them one } \\
\text { student did not show interest in participation. He } \\
\text { informed instructor that this does not add up to their } \\
\text { internal assessment marks, so he is not showing }\end{array}$ \\
\hline
\end{tabular}

\begin{tabular}{|c|c|}
\hline & $\begin{array}{l}\text { interest to take the activity seriously. Other student of } \\
\text { the team has shown interest but he was a low } \\
\text { performer, he needed a support for discussion with } \\
\text { good performing student. But as the good performing } \\
\text { student was not in this group, the team score went } \\
\text { low. }\end{array}$ \\
\hline 3 & $\begin{array}{l}\text { This team score was } 30 \% \\
\text { This group had a combination of one good performer } \\
\text { and one low performer. In this team only good } \\
\text { performing student scored the marks but low } \\
\text { performing student scored zero marks. So the team } \\
\text { score went below the median score. }\end{array}$ \\
\hline 5 & $\begin{array}{l}\text { This team score was } 27 \% \\
\text { In this group good performing student was absent. } \\
\text { Remaining were average and low performing } \\
\text { students. They would have found difficulty in } \\
\text { understanding and correlating the topic to the } \\
\text { program hence they performed less than the median } \\
\text { score. }\end{array}$ \\
\hline 8 & $\begin{array}{l}\text { This team score was } 50 \% \\
\text { In this all team members made one common mistake } \\
\text { in the quiz. This may be because all team members } \\
\text { would have misunderstood the topic in correlating it } \\
\text { to the program given to them. Hence their } \\
\text { performance has gone less than the median score. }\end{array}$ \\
\hline 10 & $\begin{array}{l}\text { This team score was 53\% } \\
\text { In this all team members made one common mistake } \\
\text { in the quiz. This may be because all team members } \\
\text { would have misunderstood the topic in correlating it } \\
\text { to the program given to them. Hence their } \\
\text { performance has gone less than the median score. }\end{array}$ \\
\hline \multicolumn{2}{|c|}{ Reason for scoring greater than or equal to median score } \\
\hline 6 & $\begin{array}{l}\text { This team score was } 90 \% \\
\text { In this team one student i.e. Good performer was very } \\
\text { active and he shows keen interest in sharing his } \\
\text { knowledge with the others. Hence good coordination } \\
\text { and learning happened between the two and the team } \\
\text { performed well. }\end{array}$ \\
\hline
\end{tabular}

\section{Conclusion and Recommendations}

In this paper, the collaborative activity carried out for a particular objective of Web Programming course was presented.Experimentally, the STAD activity was conducted for a particular course of a semester and in between the semester. This is acceptable for the purpose of research, but further it can be evaluated by application of STAD activity in a full academic semester. The challenges faced during conduction of the activity were, some students not showing interest in the activity and time management.

Based on the challenges listed and own experience of practicing in-class collaborative activity, the two most important recommendations for improving STAD activity next time are

i. As in STAD activity the students take up the quiz, but this score of the quiz was not a part of their final internal assessment marks of the course. So, few students did not show interest in participation for the activity, they took the activity casually. Next time, instructor plan is to consider STAD quiz marks (both individual and group) to be a part of their internal assessment marks of the course. Secondly, 
to promote individual accountability, the plan is to adopt "Readiness Assurance Process in Team Learning [5]."

ii. This STAD collaborative activity was carried out during the afternoon session by conducting an extra class. Some students expressed their view after completion of the activity that they would like to take up this activity during morning session classes. Also, it was observed that few students do not show much interest during afternoon sessions of the class and a few students do not turn up for afternoon classes. So, next plan is to conduct the activity during morning sessions.

\section{Acknowledgement}

The work reported in this paper is supported by the college through the TECHNICAL EDUCATION QUALITY IMPROVEMENT PROGRAMME [TEQIP-II] of the MHRD, Government of India.

\section{References}

1.Dillenbourg, P. (1999). Collaborative Learning: Cognitive and Computational Approaches. Advances in Learning and Instruction Series.Elsevier Science, Inc., PO Box 945, Madison Square Station, New York, NY 101600757.

2.Tiantong, M., \&Teemuangsai, S. (2013). Student team achievement divisions (STAD) technique through the moodle to enhance learning achievement. International Education Studies, 6(4), p85.

3.Slavin, R. (1994). Students' teams-achievement divisions. Handbook of cooperative learning, 3-19

4.Sejnost, R. L. (Ed.). (2009). Tools for Teaching in the Block. Corwin Press.

5.Michaelsen, L. K., \& Sweet, M. (2011). Team based learning. New directions for teaching and learning, 2011(128), 41-51. 